\title{
PENERAPAN PEMBELAJARAN JARAK JAUH (PJJ) DI MASA PANDEMI COVID-19
}

\author{
Kristin Mars Hutabarat \\ E-mail : kristin.mars2848@student.unri.ac.id
}

Program Studi Pendidikan Bahasa dan Sastra Indonesia, Universitas Riau

\section{Pengantar}

Pandemi Covid-19 mengakibatkan banyak sekali dampak terhadap berbagai bidang baik itu bidang kesehatan, ketenagakerjaan, ekonomi maupun pendidikan. Berbagai upaya telah dilakukan Pemerintah demi tetap terjalannya aktivitas-aktivitas pada bidang yang terdampak oleh wabah Covid-19 secara langsung maupun tidak langsung. Mulai dari memperbaharui hingga menciptakan sesuatu yang baru pun dibuat, seperti halnya pada dunia Pendidikan yang sudah tidak asing lagi kita dengar yakni penerapan Pembelajaran Jarak Jauh (PJJ).

Penerapan

Menurut Kamus Besar Bahasa Indonesia (KBBI), pengertian penerapan adalah perbuatan menerapkan, sedangkan menurut beberapa ahli, penerapan adalah suatu perbuatan mempraktekkan suatu teori, metode, dan hal lain untuk mencapai tujuan tertentu dan untuk suatu kepentingan yang diinginkan oleh suatu kelompok atau golongan yang telah terencana dan tersusun sebelumnya. Menurut Usman (2002), penerapan (implementasi) adalah bermuara pada aktivitas, aksi, tindakan, atau adanya mekanisme suatu sistem.Implementasi bukan sekedar aktivitas, tetapi suatu kegiatan yang terencana dan untuk mencapai tujuan kegiatan. Menurut Setiawan (2004) penerapan (implementasi) adalah perluasan aktivitas yang saling menyesuaikan proses interaksi antara tujuan dan tindakan untuk mencapainya serta memerlukan jaringan pelaksana, birokrasi yang efektif.

Berdasarkan pengertian-pengertian tersebut dapat disimpulkan bahwa kata penerapan (implementasi) bermuara pada aktifitas, adanya aksi, tindakan, 
atau mekanisme suatu system. Ungkapan mekanisme mengandung arti bahwa penerapan (implementasi) bukan sekedar aktifitas, tetapi suatu kegiatan yang terencana dan dilakukan secara sungguh-sungguh berdasarkan acuan norma tertentu untuk mencapai tujuan kegiatan.

\section{Model Pembelajaran}

Menurut Trianto (2010:51) Model Pembelajaran adalah suatu perencanaan atau suatu pola yang digunakan sebagai pedoman dalam melaksanakan pembelajaran dikelas atau pembelajaran dalam tutorial.

Model pembelajaran adalah kerangka konseptual yang melukiskan prosedur sistematis dalam mengorganisasikan sistem belajar untuk mencapai tujuan belajar tertentu dan berfungsi sebagai pedoman bagi perancang pembelajaran dan para pengajar dalam merencanakan dan melaksanakan aktivitas pembelajaran (Saefuddin \& Berdiati, 2014:48). Menurut Sagala (2005:175) model pembelajaran adalah kerangka konseptual yang melukiskan prosedur yang sitematis dalam mengorganisasikan pengalaman belajar peserta didik untuk mencapai tujuan belajar tertentu, dan berfungsi sebagai pedoman bagi perancang pembelajaran dan guru dalam merencanakan dan melaksanakan aktivitas belajar.

Model pembelajaran adalah pedoman berupa program atau petunjuk strategi mengajar yang dirancang untuk mencapai suatu pembelajaran (Daryanto \& Raharjo, 2012:241). Dahlan dalam Isjoni (2013:49) mengemukakan model pembelajaran dapat diartikan sebagai suatu rencana atau pola yang digunakan dalam menyusun kurikulum, mengatur materi pelajaran, dan memberi petunjuk kepada pengajar di kelas. Sedangkan pembelajaran menurut Muhammad Surya dalam Isjoni (2013:49) merupakan suatu proses perubahan yang dilakukan individu untuk memperoleh suatu perubahan perilaku yang baru secara keseluruhan, sebagai hasil dan pengalaman individu itu sendiri dalam interaksi dengan lingkungannya.

Model pembelajaran merupakan suatu rancangan (desain) yang menggambarkan proses rinci penciptaan situasi lingkungan yang memungkinkan terjadinya interaksi pembelajaran agar terjadi perubahan atau perkembangan diri peserta didik (Sukmadinata, 2012:151). Menurut Joyce \& Weil dalam Rusman 
(2014:144) berpendapat bahwa, model pembelajaran adalah suatu rencana atau pola yang bahkan dapat digunakan untuk membentuk kurikulum (rencana pembelajaran jangka panjang), merancang bahan-bahan pembelajaran, dan membimbing pembelajaran dikelas atau lingkungan belajar lain.

Model pembelajaran pada dasarnya merupakan bentuk pembelajaran yang tergambar dari awal sampai akhir yang disajikan secara khas oleh guru. Dengan kata lain, model pembelajaran merupakan bungkus atau bingkai dari penerapan suatu pendekatan, metode, dan teknik pembelajaran (Komalasari, 2010:57). Model pembelajaran ialah pola yang digunakan sebagai pedoman dalam merencanakan pembelajaran dikelas maupun tutorial. Model pembelajaran mengacu pada pendekatan yang akan digunakan, termasuk didalam tujuan-tujuan pembelajaran, tahap-tahap dalam kegiatan pembelajaran, dan pengelolaan kelas. Model pembelajaran dapat didefinisikan sebagai kerangka konseptual yang melukiskan prosedur sistematis dalam mengorganisasikan pengalaman belajar untuk mencapai tujuan belajar (Suprijono, 2010:54-55).

Kompetensi pedagogik merupakan kemampuan dan kehandalan guru dalam memahami peserta didik, membuat perencanaan dalam pelajaran, dan mengavaluasi peserta didik. Bahkan, guru harus mendorong peserta didik untuk mengembangkan dan mengaktualisasikan berbagai potensi yang ada pada dirinya (Zulhafizh, Atmazaki, \& Syahrul, 2013). Model pembelajaran adalah kerangka konseptual yang melukiskan prosedur yang sistematis dalam mengorganisasikan pengalaman belajar peserta didik untuk mencapai tujuan belajar tertentu dan berfungsi sebagai pedoman bagi perancang pembelajaran dan guru dalam merencanakan dan melaksanakan aktivitas belajar mengajar (Indrawati dan Wanwan Setiawan, 2009:27). Adapun Soekamto dalam Ahmadi dan Sofan (2008:8) mengemukakan maksud dari model pembelajaran adalah kerangka konseptual yang melukiskan prosedur yang sistematik dalam mengorganisasikan pengalaman belajar untuk mencapai tujuan belajar tertentu, dan berfungsi sebagai pedoman bagi para perancang pembelajaran dan pengajar dalam merencanakan aktivitas belajar mengajar.

Menurut Ibrahim (2000:2) model pembelajaran adalah pola interaksi siswa dengan guru di dalam kelas yang menyangkut pendekatan, strategi, metode, 
teknik pembelajaran yang diterapkan dalam pelaksanaan kegiatan belajar mengajar di kelas. Model pembelajaran adalah kerangka konseptual yang melukiskan prosedur yang sistematik dan mengorganisasikan pengalaman belajar untuk mencapai tujuan belajar tertentu dan berfungsi sebagai pedoman para perancang pembelajaran dan para pengajar dalam merencanakan dan melakukan aktivitas pembelajaran. Suryanto dan Jihad (2013:134) mengartikan model pembelajaran sebagai kerangka konseptual yang melukiskan prosedur yang sistematis dalam mengorganisasikan pengalaman belajar untuk mencapai tujuan belajar tertentu dan berfungsi sebagai pedoman bagi perancang pembelajaran dan para guru dalam merencanakan dan melaksanakan aktivitas belajar-mengajar.

Berkenaan dengan model pembelajaran, Brunce Joyce dan Marsha Weil dalam Asnawir dan Basyirudin (2002:16) mengetengahkan empat kelompok model pembelajaran, yaitu (1) model interaksi sosial, (2) model pengolahan informasi, (3) model personal humanistik, dan (4) model modifikasi tingkah laku. Kendati demikian, sering kali penggunaan istilah model pembelajaran tersebut diidentikan dengan strategi pembelajaran. Menurut Rusman (2014:136) model pembelajaran memiliki ciri-ciri sebagai berikut:

1) Berdasarkan teori pendidikan dan teori belajar dari para ahli tertentu. Model ini dirancang untuk melatih partisipasi dalam kelompok secara demokratis.

2) Mempunyai misi atau tujuan pendidikan tertentu, misalnya model berpikir induktif dirancang untuk mengembangkan proses berpikir induktif.

3) Dapat dijadikan pedoman untuk perbaikan kegiatan belajar mengajar di kelas, misalnya model synectic dirancang untuk memperbaiki kreativitas dalam pelajaran mengarang.

4) Memiliki bagian-bagian model yang dinamakan: (1) urutan langkahlangkah pembelajaran, (2) adanya prinsip-prinsip reaksi, (3) sistem sosial, dan (4) sistem pendukung. Keempat bagian tersebut merupakan pedoman praktis bila guru akan melaksanakan suatu model pembelajaran. 
5) Memiliki dampak sebagai akibat terapan model pembelajaran. Dampak tersebut meliputi: (1) dampak pembelajaran, yaitu hasil belajar yang dapat diukur, dan (2) dampak pengiring, yaitu hasil belajar jangka panjang.

6) Membuat persiapan mengajar (desain intruksional) dengan pedoman model pembelajaran yang dipilihnya.

Model pembelajaran yang ideal adalah model yang mengeksplorasi pengalaman belajar efektif, yaitu pengalaman belajar yang memungkinkan siswa mengalami atau berbuat secara langsung dan aktif dalam sebuah lingkungan belajarnya (Sukardi, 2013:30). Darsono dalam Hamdani (2011:23) mengemukakan bahwa, pembelajaran menurut aliran behavioristik adalah usaha guru membentuk tingkah laku yang diinginkan dengan menyediakan lingkungan atau stimulus. Aliran kognitif mendefinisikan pembelajaran sebagai cara guru memberikan kesempatan kepada siswa untuk berpikir dan memahami sesuatu yang sedang dipelajari. Model rancangan pembelajaran secara umum dapat diartikan sebagai tampilan grafis, suatu kerangka konseptual yang melukiskan aturan yang sistematis dalam mengorganisasikan belajar untuk mencapai tujuan pembelajaran tertentu. Dengan demikian, aktivitas belajar mengajar benar-benar merupakan kegiatan yang tertata secara sistematis dan terlaksana sesuai dengan yang telah direncanakan (Prawiradilaga, 2007:33).

Menurut penjelasan beberapa ahli diatas, dapat disimpulkan bahwa model pembelajaran adalah suatu pola atau rencana yang digunakan untuk mencapai tujuan belajar tertentu.

Pembelajaran Jarak Jauh (PJJ)

Pembelajaran adalah proses interaksi perserta didik dengan pendidik dan sumber belajar pada suatu lingkungan belajar yang meliputi guru dan siswa saling bertukar infomasi (Mutiani, M., Subiyakto, B., Jumriani, J., Aslamiah, A., \& Afrina, A. 2019). Pembelajaran menjadi suatu proses yang dimana tenaga pendidik melakukan pengembangan kreatifitas berpikir untuk meningkatkan berpikir peserta didik, kemudian juga meningkatkan kemampuan meningkatkan pengetahuan baru. Pembelajaran menjadi suatu upaya untuk meningkatkan penguasaan yang bagus terhadap mata pelajaran. Pada akhir Desember 2019, 
ditemukan Corona Virus Disease 2019 (COVID-19) DI KOTA Wuhan, China. Virus ini menyebar begitu cepat hampir ke berbagai negara, termasuk Indonesia. Munculnya virus berbahaya ini berdampak pada berbagai berbagai sektor, termasuk sektor pendidikan. Di negara Indonesia sendiri mengeluarkan kebijakan untuk memberlakukan lockdown dalam mencegah penularan, juga kebijakan Pembatasan Sosial Berskala Besar (PSBB) oleh pemerintah, dengan adanya kebijakan ini sehingga beberapa kegiatan diluar rumah diberhentikan agar mengurangi penyebaran virus.

Pengertian pelaksanaan pembelajaran jarak jauh adalah pelaksanaan pembelajaran yang hanya dilakukan secara jarak jauh dalam mendukung proses belajar yang berisi kegiatan-kegiatan bermain yang memberikan pengalaman belajar bermakna tanpa terbebani tuntutan untuk menuntaskan capaian pembelajaran sebagaimana tertuang di dalam kurikulum (Kemendikbud. 2020 : 2). Sedangkan pelaksanaan pembelajaran adalah kegiatan yang menggambarkan prosedur, dan pengorganisasian pembelajaran untuk mencapai satu kompetensi dasar yang ditetapkan. Dalam standar isi yang telah dijabarkan dalam silabus. Ruang lingkup rencana pembelajaran paling luas mencakup 1 (satu) kompetensi dasar yang terdiri atas 1 (satu) atau beberapa indikator untuk 1 (satu) kali pertemuan atau lebih. Secara definisi rencana pelaksanaan pembelajaran merupakan keseluruhan proses pemikiran dan penentuan semua aktivitas yang akan dilakukan pada masa kini dan masa yang akan datang dalam rangka mencapai tujuan (Mulyasa, 2007 : 216).

Pembelajaran jarak jauh (PJJ) mengandalkan konektivitas antara pelajar dengan pengajar secara daring dengan memanfaatkan gawai yang dimiliki untuk saling terhubung (Pakpahan \& Fitriani, 2020). Adanya PJJ sangat mewajibkan penggunaan gawai dan internet selama belajar. Pembelajaran jarak jauh mungkin bagi beberapa orang tidak asing lagi untuk terdengar. Namun, bagi mereka yang belum pernah merasakan atmosfer pembelajaran jarak jauh mungkin akan mengalami kendala dalam pelaksanaannya.

Kegiatan pembelajaran jarak jauh ditanggapi oleh masyarakat secara pro maupun kontra. Banyak dari mereka menganggap pembelajaran jarak jauh sebagai solusi yang efektif, tetapi tak sedikit pula dari mereka yang merasa keberatan terhadap praktik belajar jarak jauh. Berbagai permasalahan pun muncul yang terdiri dari permasalahan prosedural, fasilitas, maupun infrastruktur 
penunjang pembelajaran jarak jauh (Jannah, 2020). Padahal, permasalahan tersebut sejatinya minim untuk muncul guna mencapai skenario pembelajaran yang efektif di masa pandemi. Oleh karenanya, studi berikut berupaya untuk mengangkat permasalahan yang muncul terkait proses pembelajaran jarak jauh dengan harapan proses tersebut dapat ditingkatkan di kemudian hari.

Effendi dan Hartono (2005:6) menjelaskan bahwa e-learning merupakan semua kegiatan yang menggunakan media komputer dan atau internet. Chandrawati (2010) menyatakan bahwa, e-learning (electronik learning) merupakan proses pembelajaran jarak jauh dengan menggabungkan prinsipprinsip dalam proses pembelajaran dengan teknologi. Brown dan Feasey (Darmawan, 2012:26) juga menjelaskan bahwa e-learning merupakan kegiatan pembelajaran yang memanfaatkan jaringan (internet, LAN, WAN) sebagai metode penyampaian, interaksi, dan fasilitas serta didukung oleh berbagai bentuk layanan belajar. Sejalan dengan Rusman, Kurniawan \& Riyana (2012:263) yang menyatakan bahwa pembelajaran berbasis web merupakan suatu kegiatan pembelajaran yang memanfaatkan media situs (website) yang bisa di akses melalui jaringan internet. Pembelajaran berbasis web atau yang dikenal juga "web based learning" merupakan salah satu jenis penerapan dari pembelajaran elektronik (e-learning).

Menurut Romli (2012:34) Pengertian media daring secara umum adalah segala jenis atau format media yang hanya bisa diakses melalui internet berisikan teks, foto, video dan suara, sebagai sarana komunikasi secara daring, sedangkan pengertian khusus media daring dimaknai sebagai sebuah media dalam konteks komunikasi massa.

Sebuah ungkapan bijak, 'Kalau ingin melihat kualitas suatu bangsa, lihatlah kualitas gurunya'. Keberadaan guru menjadi penentu kualitas-mutu pendidikan suatu bangsa. Minister of Education, Culture and Science (2013) guru menjadi penentu kualitas pendidikan.Guru mampu memberikan peran dan warna suatu bangsa dalam kontek pelaksanaan pendidikan sehingga patut menjadi perhatian (Mustafa, Hermandra, \& Zulhafizh, 2018)

Menurut Munir (2009:171-172) manfaat e-learning dapat dilihat dari dua sudut, yaitu dari sudut peserta didik dan guru:

1) Sudut peserta didik 
a) Belajar di sekolah-sekolah kecil di daerah-daerah miskin untuk mengikuti mata pelajaran tertentu yang tidak dapat diberikan oleh sekolahnya.

b) Mengikuti program pendidikan keluarga di rumah (home schoolers) untuk mempelajari materi yang tidak dapat diajarkan oleh orang tuanya, seperti bahasa asing dan keterampilan di bidang komputer.

c) Merasa phobia dengan sekolah atau peserta didik yang di rawat di rumah sakit maupun di rumah, yang putus sekolah tapi berniat melanjutkan pendidikannya, maupun peserta didik yang berada di berbagai daerah atau bahkan yang berada di luar negeri, dan

d) Tidak tertampung di sekolah konvensional untuk mendapatkan pendidikan.

2) Guru

a) Lebih mudah melakukan pemutakhiran bahan-bahan yang menjadi tanggung jawabnya sesuai dengan tuntutan perkembangan keilmuan yang terjadi.

b) Mengembangkan diri atau melakukan penelitian guna peningkatan wawasannya karena waktu luang yang dimiliki relatif lebih banyak.

c) Mengontrol kegiatan belajar peserta didik. Bahkan guru juga dapat mengetahui kapan peserta didiknya belajar, topik apa yang dipelajari, berapa lama suatu topik dipelajari, serta berapa kali topik tertentu dipelajari ulang.

d) Mengecek apakah peserta didik telah mengerjakan soal-soal latihan setelah mempelajari topik tertentu, dan

e) Memeriksa jawaban peserta didik dan memberitahukan hasilnya kepada peserta didik.

Selain itu, manfaat e-learning dengan penggunaan internet, khususnya dalam pembelajaran jarak jauh antara lain:

1) Guru dan siswa dapat berkomunikasi dengan mudah dan cepat melalui fasilitas internet tanpa dibatasi oleh tempat, jarak dan

1. waktu. Secara regular atau kapan saja kegiatan berkomunikasi bisa dilaksanakan.

2) Guru dan siswa dapat menggunakan materi pembelajaran yang ruang lingkup (scope) dan urutan (sekuensnya) sudah sistematis terjadwal 
melalui internet.

3) Dengan e-learning dapat menjelaskan materi pembelajaran yang sulit dan rumit menjadi mudah dan sederhana. Selain itu, materi pembelajaran dapat disimpan dikomputer, sehingga siswa dapat mempelajari kembali atau mengulang materi pembelajaran yang telah dipelajarinya setiap saat dan dimana saja sesuai dengan keperluannya.

4) Mempermudah dan mempercepat mengakses atau memperoleh banyak informasi yang berkaitan dengan materi pembelajaran yang dipelajarinya dari berbagai sumber informasi dengan melakukan akses di internet.

5) Internet dapat dijadikan media untuk melakukan diskusi antara guru dengan siswa, baik untuk seorang pembelajar, atau dalam jumlah pembelajar terbatas, bahkan massal.

6) Peran siswa menjadi lebih aktif mempelajari materi pembelajaran, memperoleh ilmu pengetahuan atau informasi secara mandiri, tidak mengandalkan pemberian dari guru, disesuaikan pula dengan keinginan dan minatnya terhadap materi pembelajaran.

7) Relatif lebih efisien dari segi waktu, tempat dan biaya.

8) Bagi pembelajar yang sudah bekerja dan sibuk dengan kegiatannya sehingga tidak mempunyai waktu untuk datang ke suatu lembaga pendidikan maka dapat mengakses internet kapanpun sesuai dengan waktu luangnya.

9) Dari segi biaya, penyediaan layanan internet lebih kecil biayanya dibanding harus membangun ruangan atau kelas pada lembaga pendidikan sekaligus memeliharanya, serta menggaji para pegawainya.

10) Memberikan pengalaman yang menarik dan bermakna bagi siswa karena dapat berinteraksi langsung, sehingga pemahaman terhadap materi akan lebih bermakna pula (meaning full), mudah dipahami, diingat dan mudah 
pula untuk diungkapkan.

11) Kerja sama dalam komunitas online yang memudahkan dalam transfer informasi dan melakukan suatu komunikasi sehingga tidak akan kekurangan sumber atau materi pembelajaran.

12)Administrasi dan pengurusan terpusat sehingga memudahkan dalam melakukan akses atau dalam operasionalnya.

13) Membuat pusat perhatian dalam pembelajaran.

Menurut Siahaan (2002) setidaknya ada 3 (tiga) fungsi pembelajaran elektronik terhadap kegiatan pembelajaran di dalam kelas (classroom instruction), yaitu:

1. Suplemen (tambahan)

Dikatakan berfungsi sebagai suplemen, apabila peserta didik mempunyai kebebasan memilih, apakah akan memanfaatkan materi pelajaran elektronik atau tidak. Dalam hal ini, tidak ada kewajiban/keharusan bagi peserta didik untuk mengakses materi pembelajaran elektronik. Sekalipun sifatnya operasional, peserta didik yang memanfaatkannya tentu akan memiliki tambahan pengetahuan atau wawasan.

2. Komplemen (pelengkap)

Dikatakan berfungsi sebagai komplemen, apabila materi e-learning diprogramkan untuk melengkapi materi pembelajaran yang diterima siswa di dalam kelas. Sebagai komplemen berarti materi e-learning di programkan untuk menjadi materi encrichment (pengayaan) atau remedial bagi peserta didik di dalam mengikuti kegiatan pembelajaran konvensional.

Sebagai encrichment, apabila peserta didik dapat dengan cepat menguasai/memahami materi pelajaran yang disampaikan guru secara tatap muka diberikan kesempatan untuk mengakses materi e-learning yang memang secara khusus dikembangkan untuk mereka. Tujuannya agar semakin memantapkan tingkat penguasaan peserta didik terhadap materi pelajaran yang disajikan guru di kelas. Sebagai remedial, apabila peserta didik mengalami kesulitan dalam memahami materi pelajaran yang disampaikan guru secara tatap 
muka di kelas. Tujuannya agar peserta didik semakin lebih mudah memahami materi pelajaran yang disajikan guru di kelas.

3. Subtitusi (pengganti)

Tujuan dari e-learning sebagai pengganti kelas konvensional adalah agar peserta didik dapat secara fleksibel mengelola kegiatan perkuliahan sesuai dengan waktu dan aktivitas lain sehari-hari. Ada 3 (tiga) alternatif model kegiatan pembelajaran yang dapat diikuti peserta didik:

1) Sepenuhnya secara tatap muka (konvensional).

2) Sebagian secara tatap muka dan sebagian lagi melalui internet, atau bahkan,

3) Sepenuhnya melalui internet.

\section{Penutup}

Perencanaan pembelajaran jarak jauh dipersiapkan untuk menghadapi adanya pandemi covid-19 karena dalam kondisi darurat, maka pembelajaran jarak jauh dipilih. Karena itu pembelajaran jarak jauh sebagai alternatif pembelajaran yang dilakukan agar KBM tetap berjalan. Dalam banyak berkonsultasi, diskusi serta sharing mengenai perkembangan belajar anak selama PJJ ini. Dengan demikian sekolah dan orang tua dapat saling membantu dan bekerjasama dalam proses kegiatan pengawasan pembelajaran jarak jauh yang masih diterapkan selama pandemi covid-19 serta meningkatkan dan menjaga komunikasi antara sekolah dengan orang tua agar ketika siswa sedang belajar tetap terawasi dengan baik.

Selama implementasi pembelajaran jarak jauh ini seringkali ditemukan kendala ataupun ketidaksesuaian dengan pembelajaran yang seharusnya, banyak yang mengira tanggung jawab pengajar dalam melaksanakan PJJ jauh lebih ringan ketimbang dengan Pembelajaran tradisional. Penggunaan media internet/ e-learning memiliki kendala yang cukup besar, koneksi jaringan dan kesalahan teknis seperti server down and error menghambat keberhasilan pembelajaran. 
Oleh karena itu, diharapkan kreativitas guru dalam memberikan pembelajaran agar menarik minat belajar siswa sehingga berdampak kepada prestasi siswa. Selain itu sangat dibutuhkan bantuan oleh pemerintah untuk memberikan fasilitas yang mendukung pelaksanaan pembelajaran jarak jauh ini. Dengan begitu, pelaksanaan pembelajaran jarak jauh dapat beejalan lancar dan efektif. 
Referensi

Daryanto, dan Mulyo Rahardjo.(2012). Model Pembelajaran Inovatif. Yogyakarta: Gava Media.

Isjoni. (2013). Cooperative Learning: Mengembangkan Kemampuan Belajar Kelompok. Bandung: Alfabeta.

Jannah, S. M. (2020). https://tirto.id/segudang-masalah-belajar-darirumah-karena-corona-covid-19-eGqQ. Diambil kembali dari Tirto: https://tirto.id/segudang-masalah-belajar-dari-rumah-karena-corona-covid-19$\underline{\mathrm{eGqQ}}$

Mustafa, M. N., Hermandra, \& Zulhafizh. (2018). Strategi Inovatif: Gaya Guru Sukses dalam Dunia Pendidikan. Yogyakarta: Diandra Kreatif.

Mutiani, M., Subiyakto, B., Jumriani, J., Aslamiah, A., \& Afrina (2019). Laporan Penelitian: Relevansi Modal Sosial Dalam Pembelajaran IPS (Studi Kasus Dalam Sistem Zonasi Di SMP Negeri Kota Banjarmasin).

Nurdin Usman, (2002), Konteks Implementasi Berbasis Kurikulum, Bandung, CV Sinar Baru

Pakpahan, R., \& Fitriani, Y. (2020). Analisa Pemanfaatan Teknologi Informasi dalam Pembelajaran Jarak Jauh di Tengah Pandemi Virus Corona COVID-19. Journal of Information System, Applied, Management, Accounting and Research, 4(2), 30-36.

Rusman. (2014). Model-model Pembelajaran (Mengembangkan Profesionalisme Guru). Jakarta: Raja Grafindo Persada.

Saefuddin, Azis., \& Berdiati, Ika. (2014). Pembelajaran Efektif. Bandung: PT Remajara Rosdakarya.

Setiawan, Guntur.(2004). Impelemtasi dalam Birokrasi Pembangunan. Jakarta: Balai Pustaka.

Sukmadinata, Nana Syaodih. (2012). Metode Penelitian Pendidikan. Bandung: PT. Remaja Rosdakarya.

Trianto.( 2010). Model Pembelajaran Terpadu, Konsep, Strategi dan Implementasinya dalam KTSP. Jakarta: Bumi Aksara.

Zulhafizh, Atmazaki, \& Syahrul R. (2013). Kontribusi Sikap dan Motivasi Belajar Siswa terhadap Hasil Belajar Bahasa Indonesia. Jurnal Bahasa, Sastra dan Pembelajaran, 1 (2), 13-28. 


\section{*Data Penulis}

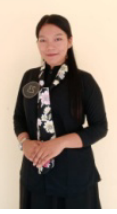

Kristin Mars Hutabarat, lahir di Pekanbaru, 27 Januari 2000. Pada tahun akademik 2018 hingga sekarang, la melanjutkan studi pada strata satu Jurusan Pendidikan Bahasa dan Seni di Program Studi Pendidikan Bahasa dan Sastra Indonesia FKIP Universitas Riau melalui jalur SBMPTN(Seleksi Bersama Masuk Perguruan Tinggi Negeri). Hingga saat ini dia pernah menjadi salah satu penulis dalam buku Sangkala (Antologi Cerpen)dan Intuisi (Antalogi Puisi Enam baris).

Kontak: Hp/WA : 082385723954

Email : kristin.mars2848@student.unri.ac.id 